\title{
ADJUVANT INTERFERENCE ON SPRAY SOLUTION PROPERTIES OF 2,4- D AND DICAMBA HERBICIDES AND THEIR EFFICACY FOR Ipomoea SPP. CONTROL
}

\author{
INTERFERENCIA DE ADJUVANTES NAS PROPRIEDADES DE CALDA DOS \\ HERBICIDAS 2,4-D E DICAMBA E SUA EFICÁCIA NO CONTROLE DE Ipomoea \\ $S P P$.
}

\section{Roberto Costa AVILA NETO'; ${ }^{1}$ Adriano Arrué MELO²; André da Rosa ULGUIM²; Rafael Munhoz PEDROSO ${ }^{3}$; Geovana Facco BARBIERI ${ }^{4}$; Cassiano Salin PIGATTO ${ }^{4}$; Eric Fernandes LUCHESE ${ }^{2}$}

1. Universidade Federal de Santa Maria - UFSM, Departamento de defesa fitossanitária, Santa Maria, RS, Brasil. roberto.aneto@hotmail.com; 2. Universidade Federal de Santa Maria - UFSM, Departamento de defesa fitossanitária, Santa Maria, RS, Brasil; 3. Universidade do Estado de São Paulo - USP, Departamento de produção vegetal, Piracicaba, SP, Brasil; 4. Universidade Federal de Pelotas - UFPel, Departamento de fitossanidade, Pelotas, RS, Brasil.

\begin{abstract}
Synthetic auxin herbicides constitute major alternatives for managing tough-to-kill weeds such as Ipomoea spp. Adjuvant use is known to positively affect the biological efficacy of pesticides by modifying key spraying solution and droplet properties. Determining to what extent the use of adjuvants could change spray solution parameters and affect synthetic auxin herbicides' efficiency for Ipomoea spp. control were the research goals. The study was conducted in two phases: laboratory and field, respectively. In the laboratory, the $\mathrm{pH}$, the surface tension, and the resources of the herbicide drops were measured. In the field, weed control was evaluated. All adjuvants modified spray solution properties, lowering surface tension values. Most adjuvants decreased $\mathrm{pH}$ values as well as number and density of droplets due to an increase in droplet size. Regardless of adjuvant usage, Ipomoea spp. control levels rose more rapidly following 2,4-D spraying rather than dicamba, resulting in lower biomass accumulation when the former was used. Dicamba-containing treatments displayed slightly but significantly lower Ipomoea spp. control levels at the end of the evaluation period. Herbicide efficacy for Ipomoea spp. control was not improved upon the addition to the spray solution of any of the tested adjuvants. Adjuvant use altered spraying solution and droplet properties. 2,4-D spraying allowed for lower Ipomoea spp. biomass and greater control levels relative to dicamba, suggesting it might constitute a better option for Ipomoea spp. control. Even though herbicide efficacy was not improved with adjuvants, their use should still be considered given favorable spraying solution alterations, mainly with some alteration in droplet sizes despite the use of similar spray nozzles tips - maintaining weed control efficacy.
\end{abstract}

KEYWORDS: Auxin. Morningglories. pH. Surface Tension.

\section{INTRODUCTION}

Synthetic auxins are an important class of herbicides, which reproduce the action of endogenous hormones naturally present in plants, albeit with more persistent and intense physiological effects (GROSSMANN 2010). The development and release of auxin-tolerant crops are expected to lead to the more frequent use of auxin herbicides in Brazil, where these are commonly used in pre-plant applications in association with glyphosate for improved control of glyphosate-tolerant or -resistant weeds (GREEN 2014; TAKANO et al., 2013).

Many weed species in the Ipomoea genus (Convolvulaceae) currently present management challenges to growers in Brazil and worldwide. These tough-to-kill weeds are commonly called "morning glories" and display annual life cycles and long, creeping stems (CAMPOS et al., 2009). Due to their natural tolerance to glyphosate, Ipomoea spp. chemical control requires the use of other herbicides. For instance, Ipomoea triloba L. control is more easily achieved with the synthetic auxin herbicide 2,4-D rather than glyphosate applications (CHAUHAN; ABUGHO, 2012) similarly, Ipomoea lacunosa $\mathrm{L}$. can be properly managed via dicamba or 2,4-D applications (LEON, FERRELL, SELLERS, 2016).

Weed control levels achieved with auxin herbicides can be severely affected by the spraying technology utilized during applications. The addition of adjuvants such as methylated soybean oil to ${ }^{14} \mathrm{c}$-aminocyclopyrachlor has been shown to hasten the absorption of this auxin herbicide in 
Albizia julibrissin Durazz. Plants (KOEPKE-HILL et al., 2012). This demonstrates the potential for adjuvants to play a major role in increasing the biological efficacy of pesticides, especially herbicides. Some benefits resulting from adjuvant usage derive from processes taking place in the spraying tank-mix, such as $\mathrm{pH}$ and droplet size and quantity alterations, and reduction of surface tension (GIMENES et al., 2013; MELO et al., 2019).

Spraying solution $\mathrm{pH}$ can greatly impact pesticide efficacy. For instance, faster herbicide degradation in the tank-mix has been reported for bromoxynil and trifluralin herbicides when the spray solution $\mathrm{pH}$ is slightly above 7.0 (CHELMEAYALA, EL-DIN, SMITH, 2010). There can be, however, opposite responses as control of Ambrosia trifida L. and Chenopodium album L. achieved with saflufenacil applications has been shown to be improved when solution $\mathrm{pH}$ was around 9.0 (ROSKAMP; JOHNSON, 2013). Similarly, ammonium-glufosinate has been shown to control A. trifida more effectively and Amaranthus palmeri S. Watson. plants when spraying solution $\mathrm{pH}$ is in 9.0 too (DEVKOTA; JOHNSON, 2016), further demonstrating the importance of adjusting spray solution $\mathrm{pH}$ when dealing with herbicide molecules capable of acquiring charges (i.e. undergoing dissociation).

Adjuvant-induced changes in spray solution surface tension have also been shown to impact herbicide efficiency. Lower surface tension can improve herbicide spray wettability by reducing the contact angle between water droplets and leaves (COSTA et al., 2017). Interactions among adjuvants and herbicide molecules can impact other spraying mixture properties such as average droplet sizes, with direct implications on pesticide use and efficacy. Droplet size alterations might impair weed control efficiency of either systemic or contact herbicides, also leading to greater spray drift potential and damage to non-target organisms (BUTTS et al., 2018). Studies evaluating the efficacy of dicamba and 2,4-D herbicides sprayed at average droplet sizes ranging from 204 to $628 \mu \mathrm{m}$ found a significant drop in control efficacy of soybean (Glycine $\max$ (L.) Merr.) and sunflower (Helianthus annuus L.) plants when fine droplet sizes were used (e.g. $228 \mu \mathrm{m}$ and below) (CREECH et al., 2016).

There is a pressing need for new studies to evaluate possible effects and interactions arising from the use of different adjuvants when mixed with either 2,4-D or dicamba herbicides. Such information has clear implications on decisionmaking made at the field level, as adjuvant usage can prove a key factor affecting 2,4-D and dicamba efficiency for weed control. The objective of this research study was to assess whether the addition of several adjuvants to either 2,4-D or dicamba herbicides can (a) modify spraying solution properties, such as surface tension, solution $\mathrm{pH}$ and droplet sizes, and (b) impact Ipomoea spp. control efficiency.

\section{MATERIAL AND METHODS}

\section{Laboratory studies: spray solution properties}

The first phase of this study was conducted in research laboratories located at the Department of Plant Defense of the Federal University of Santa Maria (UFSM), Santa Maria RS, Brazil. In order to determine spray solution parameters of herbicide and adjuvant associations, several treatments were arranged in a $2 \times 9$ factorial scheme at which factor $\mathrm{A}$ consisted of 2,4-D and dicamba herbicides. Factor B was comprised of eight commercially available adjuvants and untreated control treatment, as indicated in Table 1.

Herbicide rates were chosen following recommendations for Ipomoea grandifolia $\mathrm{L}$. control (AGROFIT, 2019). For each treatment (Table 1), $500 \mathrm{ml}$ of solution were prepared using deionized water ( $\mathrm{pH}$ 6.5); $200 \mathrm{ml}$ were then used for measuring solution $\mathrm{pH}$ and surface tension. Measurements of the latter were taken in a Goniometer (DSA25 Drop Shape Analyzer, KRUSS Gmbh, Hamburg, Germany) using the pendant drop technique (STAUFFER, 1964). Solution $\mathrm{pH}$ was measured using a hm-1072 portable digital pHmeter (Highmed Solutions, Sao Paulo, SP Brazil) following calibration with buffer solutions, as required; readings were taken on $100 \mathrm{ml}$ of solution from each treatment.

The remaining amount of $300 \mathrm{ml}$ per treatment was employed at trials aiming at assessing spray solution characteristics. To this end, treatments were applied using a bench-type track sprayer (DeVries Manufacturing, Hollandale, MN) equipped with XR 100015 flat-fan nozzles (Spraying Systems, Wheaton, IL) calibrated to deliver $150 \mathrm{~L} \mathrm{ha}^{-1}$ at $206 \mathrm{kPa}$. For each treatment (Table 1), three water-sensitive paper pieces were placed along the spraying chamber to collect aqueous droplets during the application. The evaluated characteristics were droplet density (number of droplets $\mathrm{cm}^{-2}$ ), number of droplets, mean droplet diameter $(\mu \mathrm{m})$, and volumetric mean diameter (VMD, expressed in $\mu \mathrm{m})$, as well as coverage (\%). Analyses were performed using the 
software DropScope (SprayX Spraying Experts, Sao

Carlos, SP Brazil).

Table 1. List of herbicides and adjuvants employed at the present work, and respective use rates.

\begin{tabular}{|c|c|c|c|}
\hline \multicolumn{2}{|c|}{ Herbicides (Commercial products) } & \multirow{2}{*}{$\frac{\text { Active ingredient }}{2,4-\mathrm{D}}$} & \multirow{2}{*}{$\frac{\operatorname{Rate}^{1}\left(\mathrm{~g} \mathrm{ae} \mathrm{ha}^{-1}\right)}{480}$} \\
\hline U-46 prime ${ }^{\circledR}$ & & & \\
\hline Atectra $^{\circledR}$ & & Dicamba & 480 \\
\hline $\begin{array}{l}\text { Adjuvants (Commercial } \\
\text { products) }\end{array}$ & Active ingredient & Class & Rate $(\% \mathrm{v} / \mathrm{v})$ \\
\hline $\mathrm{DASH}^{\circledR} \mathrm{HC}$ & $\begin{array}{l}\text { Fatty acid esters }+ \\
\text { alkoxylated alcohols- } \\
\text { phosphate esters }\end{array}$ & Mineral oil & 0.50 \\
\hline $\operatorname{Li} 700^{\circledR}$ & $\begin{array}{l}\text { Phosphatidylcholine }+ \\
\text { propionic acid }\end{array}$ & Multifunctional & 0.50 \\
\hline $\mathrm{NAFT}^{\circledR}$ & Nitrogen & Multifunctional & 0.05 \\
\hline Orobor $^{\circledR}$ & Orange residue oil & Multifunctional & 0.50 \\
\hline $\mathrm{TA} 35^{\circledR}$ & $\begin{array}{l}\text { Sodium Lauryl Ether } \\
\text { Sulfate }\end{array}$ & Multifunctional & 0.05 \\
\hline Extremo $^{\circledR}$ & $\begin{array}{l}\text { fatty acid methyl esters } \\
\text { of vegetable oils }\end{array}$ & Antievaporant and tensoactive & 0.50 \\
\hline Veget'Oil $^{\circledR}$ & $\begin{array}{c}\text { Fatty acid esters of } \\
\text { vegetable origin }\end{array}$ & Vegetable oil & 0.50 \\
\hline Silwet $^{\circledR}$ L-77 & Trisiloxane ethoxylate & Adhesive spreader & 0.05 \\
\hline
\end{tabular}

${ }^{1}$ Acid equivalent.

Field studies: Ipomoea spp. control levels following 2,4-D and dicamba applications

Field trials were conducted at UFSM's Department of Plant Defense station. An additional treatment consisting of untreated control means, yielding a $2 \times 9+1$ factorial scheme (Table 1). Experimental units consisted of $7.5 \mathrm{~m}^{2}$ plots. Prior to treatment spraying, an application of sethoxydim at $184 \mathrm{~g}$ a.i. ha $^{-1}$ ensured plots were rid of grassy weeds. The remaining broadleaf weed flora was then characterized, and Ipomoea spp. prevailed as the most frequent and homogenous species with an average density of 4.8 plants $\mathrm{m}^{-2}$; these were chosen as targets for 2,4-D and dicamba herbicide applications.

Treatments (Table 1) were sprayed using a $\mathrm{CO}_{2}$-pressurized backpack sprayer equipped with XR 100015 flat-fan nozzles calibrated to deliver 150 $\mathrm{L} \mathrm{ha}^{-1}$ at $206 \mathrm{kPa}$. At the time of spraying, Ipomoea spp. plants were at the 5-leaf growth stage. Percent weed control was then evaluated from 7 to 28 days after treatment (DAT) using a 0-to-100 scale, at which 0 indicates the absence of herbicide-induced symptoms, whereas 100 stands for plant death (FRANS, 1986). Aboveground biomass was harvested at 28 DAT from a $0.25 \mathrm{~m}^{2}$ area randomly chosen at the corners of each plot; plant samples were taken to a hot air dryer at $60{ }^{\circ} \mathrm{C}$. Upon reaching constant weight, dry aboveground biomass was determined for each sample, and results presented on a per square meter basis.

\section{Experimental design and data analysis}

Laboratory trials were conducted following a completely random design, whereas field studies followed a randomized complete block design. Surface tension measurements taken using the goniometer were replicated 10 times to ensure consistency of results and were expressed in $\mathrm{mN} \mathrm{m}^{-}$ 1. Three pieces of water-sensitive paper were used per treatment for measurements of droplet density, quantity, and size, as well as coverage, and constituted replications. Experimental units were replicated four times during field trials. Data were subject to analysis of variance (ANOVA) using the expdes.pt package on $\mathrm{R}$ ( $\mathrm{R}$ Core Team, Vienna, Austria) (FERREIRA, CAVALCANTI, NOGUEIRA, 2014) and pooled in the absence of a significant treatment by run interaction. Treatment means were compared using Scott-Knott's test $(\alpha=$ 0.05 ) when appropriate. 


\section{RESULTS AND DISCUSSION}

\section{Effects on spray solution and droplet properties}

Analysis of data normality (Shapiro-Wilk test) and homogeneity (O'Neill-Matthews test) indicated no data transformation was required. Adjuvants affected spray solution and droplet parameters differently across treatments. Analysis of variance indicated a significant interaction between factor A (2,4-D and dicamba herbicides) and B (adjuvants) for surface tension values (Table 2). However, no significant $\mathrm{AxB}$ interaction was observed for droplet density, number, mean diameter, and volumetric mean diameter, as well as coverage.

\section{Effects on spray solution $\mathrm{pH}$}

The addition of most adjuvants to the spray solution lowered average $\mathrm{pH}$ values (Table 2); products such as $\mathrm{DASH}^{\circledR} \mathrm{HC}$ and $\mathrm{Li}^{\circledR} 700^{\circledR}$, when mixed with dicamba, caused the $\mathrm{pH}$ to drop to values below 4.0. However, Extremo ${ }^{\circledR}$ and Silwet ${ }^{\circledR}$ L-77 adjuvants increased solution $\mathrm{pH}$ to values near or above 7.0. Given that the optimum $\mathrm{pH}$ values for 2,4-D applications range from 4 to 6 (DEVKOTA and JOHNSON, 2019). Some adjuvants could decrease weed control efficacy achieved by 2,4-D applications due to less-than-optimal spraying conditions. Such deleterious effect, however, was not observed at the present work, as presented in item 3.2. Literature is scarce regarding spray solution $\mathrm{pH}$ impacts on dicamba use and efficiency. Spraying dicamba when tank-mix $\mathrm{pH}$ drops below 5.0 is illegal since it increases its volatility (and hence drift) potential (MUELLER and STECKEL, 2019) suggesting that employing $\mathrm{DASH}^{\circledR} \mathrm{HC}$ or $\mathrm{Li} 700^{\circledR}$ in dicamba applications might require the use of additional products to increase spray solution $\mathrm{pH}$.

Table 2. Average $\mathrm{pH}$ and surface tension values for multiple combinations between adjuvants and 2,4-D or dicamba herbicides.

\begin{tabular}{|c|c|c|c|c|}
\hline \multirow{3}{*}{ Adjuvants } & \multicolumn{2}{|c|}{$\mathrm{pH}$} & \multicolumn{2}{|c|}{ Surface tension $\left(\mathrm{mN} \mathrm{m}^{-1}\right)$} \\
\hline & \multicolumn{4}{|c|}{ Herbicides } \\
\hline & $2,4-\mathrm{D}$ & Dicamba & $2,4-\mathrm{D}^{1}$ & Dicamba \\
\hline No adjuvant & 5.8 & 5.9 & $70.05 \mathrm{Ba}$ & $72.17 \mathrm{Aa}$ \\
\hline $\mathrm{DASH}^{\mathbb{R}} \mathrm{HC}$ & 4.4 & 3.5 & $44.11 \mathrm{Ab}$ & $41.68 \mathrm{Bb}$ \\
\hline $\operatorname{Li} 700^{\circledR}$ & 4.2 & 3.9 & $36.98 \mathrm{Ad}$ & $37.09 \mathrm{Ac}$ \\
\hline NAFT $^{\circledR}$ & 5.6 & 5.8 & $41.29 \mathrm{Ac}$ & $42.82 \mathrm{Ab}$ \\
\hline Orobor $^{\circledR}$ & 5.6 & 5.8 & $30.32 \mathrm{Bf}$ & $32.28 \mathrm{Ad}$ \\
\hline TA35 $^{\circledR}$ & 5.7 & 5.7 & $32.79 \mathrm{Ae}$ & $33.69 \mathrm{Ad}$ \\
\hline Extremo $^{\circledR}$ & 7.2 & 7.2 & $25.37 \mathrm{Ag}$ & $25.60 \mathrm{Ae}$ \\
\hline Veget'Oil $^{\circledR}$ & 5.7 & 5.7 & $30.78 \mathrm{Bf}$ & $33.51 \mathrm{Ad}$ \\
\hline Silwet $^{\circledR}$ L-77 & 6.6 & 7.2 & $19.89 \mathrm{Bh}$ & $22.06 \mathrm{Af}$ \\
\hline CV (\%) & - & - & & \\
\hline
\end{tabular}

${ }^{1}$ Values followed by the same lower-case letter within columns and upper-case letters within lines are not statistically different according to Scott-Knott's test $(\alpha=0.05)$.

\section{Surface tension changes in response to adjuvant usage}

Adding adjuvants to the spray solution significantly lowered its surface tension relative to the control solution, which was kept adjuvant-free throughout the trial (Table 2). Regardless of herbicide present in the mix, Silwet ${ }^{\circledR}$ L-77 caused the largest drop in surface tension, followed by Extremo $^{\mathbb{B}}$. Similar results can be found in the literature, as Silwet ${ }^{\circledR}$ L-77 also caused a large decrease in surface tension when added to glyphosate or saflufenacil herbicides (CASTRO et al., 2018). It should be noted that such decrease in surface tension caused by adjuvants could potentially increase the amount of pesticide active ingredient which gets retained at the foliage and improve its efficacy, as has been shown for the insecticide chlorantraniliprole when sprayed onto maize (Zea mays L.) plants (MELO et al., 2019). Accordingly, better retention of herbicide molecules onto the leaf surface could lead to greater weed control levels, since a lack of proper coverage is 
known to lead to poor weed control (BUTTS et al., 2018). It is also noteworthy the fact that DASH ${ }^{\circledR} \mathrm{HC}$ caused a larger drop in surface tension when it was added to dicamba relative to 2,4-D-containing solutions; however, an opposite response was

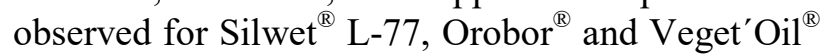
adjuvants (Table 2), indicating that responses are active ingredient-specific, demanding each case be carefully analyzed.

In some nozzles, such large drops in surface tension values set forth by adding adjuvants to the spray solution might cause an overall reduction in droplet sizes, which, in turn, is known to dictate drift potential onto non-target organisms, except for air injection nozzles, whose effect is the oppose (MOTA; ANTUNIASSI, 2013). Lowering interfacial tension knowingly promotes emulsification and eases droplet break-up, hence facilitating droplets rupture as they exit through the nozzle tip's orifice (DE SCHAMPHELEIRE et al., 2009) potentially increasing drift losses and damage to non-target areas, which cannot be overlooked when auxin herbicides are sprayed. Therefore, choosing an adjuvant for auxin herbicide spraying represents an essential step to prevent an excessive decrease in surface tension values which could lead to large drift losses and decrease weed control efficacy.

\section{Coverage and droplet density, number, and size}

Coverage values ranged from 20.5 to $42.9 \%$. Treatments containing 2,4-D had an overall larger droplet density and number, as well as coverage relative to treatments containing dicamba (Table 3). 2,4-D's better coverage of water-sensitive paper might be related to its ability to lower surface tension values, suggesting the latter could effectively improve foliage coverage. Droplet density and number (Table 3) varied differently across adjuvant sources; however, most adjuvants were found to decrease mean droplet density and droplet numbers, as they caused an increase in mean droplet diameters relative to the adjuvant-free control treatment. Exceptions to this statement were treatments with Orobor $^{\mathbb{R}}, \mathrm{TA} 5^{\mathbb{B}}{ }^{\text {and }}$ axtremo ${ }^{\mathbb{R}}$, which scored similar values of droplet density and droplet numbers relative to the control treatment. It should be noted, however, that the largest decrease in surface tension caused by Extremo ${ }^{\mathbb{B}}$ and Silwet ${ }^{\mathbb{B}}$ L-77 adjuvants could have increased the values of these variables by allowing for droplet coalescence to take place.

Adding DASH ${ }^{\circledR} \mathrm{HC}$ and Veget' $\mathrm{Oil}^{\circledR}$ to the solution was found to cause the largest increase in droplet volumetric mean diameter (VMD; Table 3) across all treatments, producing extremely coarse and coarse droplet sizes, respectively. However, all other treatments produced droplet sizes that fall within the medium-size category according to the classification system developed by the "American Society for Agricultural and Biological Engineers" (HEWITT, 2008), as was also observed for the control treatment that was kept adjuvant-free throughout this trial. Accordingly, mean droplet diameters were also the largest when $\mathrm{DASH}^{\circledR} \mathrm{HC}$ and Veget'Oil ${ }^{\circledR}$ were used relative to other treatments. Such larger droplet sizes, in turn, resulted in these adjuvants displaying the lowest number of droplets of all treatments (Table 3). Adding products to the spray solution mix is known to potentially alter droplet sizes. Adding ammonium sulfate and polymers to the spray solution have been shown to cause droplet size increases relative to the isolated dicamba application (Roskamp and Johnson, 2013). Overall, these results suggest that $\mathrm{DASH}^{\circledR} \mathrm{HC}$ and $\mathrm{Veget}^{\prime} \mathrm{Oil}{ }^{\circledR}$ could be used when larger droplets sizes are desired, which in turn is known to decrease drift losses - a major issue when dealing with auxin herbicide applications due to their potential damage to broadleaf crops in the surrounding areas. 
Table 3. Droplet density and number, coverage, volumetric mean diameter (VMD) and mean diameter values obtained for 2,4-D and dicamba combinations with adjuvants.

\begin{tabular}{|c|c|c|c|c|c|}
\hline Treatment & $\begin{array}{l}\text { Droplet }^{1} \text { density } \\
\text { (number of } \\
\text { droplets } \mathrm{cm}^{-2} \text { ) }\end{array}$ & $\begin{array}{l}\text { Number of } \\
\text { droplets }\end{array}$ & Coverage (\%) & $\begin{array}{l}\text { VMD } \\
(\mu \mathrm{m})\end{array}$ & $\begin{array}{l}\text { Mean diameter } \\
(\mu \mathrm{m})\end{array}$ \\
\hline \multicolumn{6}{|c|}{ Herbicides } \\
\hline 2,4-D & $380.50 \mathrm{a}$ & $1982.85 \mathrm{a}$ & $30.02 \mathrm{a}$ & 347.92 a & $166.93 \mathrm{a}$ \\
\hline Dicamba & $323.81 \mathrm{~b}$ & $1689.52 \mathrm{~b}$ & $26.87 \mathrm{~b}$ & $337.81 \mathrm{a}$ & $167.68 \mathrm{a}$ \\
\hline \multicolumn{6}{|c|}{ Adjuvants } \\
\hline No adjuvant & $479.92 \mathrm{a}$ & $2552.00 \mathrm{a}$ & $27.28 \mathrm{~b}$ & $257.99 \mathrm{e}$ & $141.35 \mathrm{~d}$ \\
\hline $\mathrm{DASH}^{\circledR} \mathrm{HC}$ & $224.82 \mathrm{c}$ & $1195.00 \mathrm{c}$ & $42.87 \mathrm{a}$ & $637.50 \mathrm{a}$ & $235.60 \mathrm{a}$ \\
\hline $\operatorname{Li} 700^{\circledR}$ & $152.72 \mathrm{c}$ & $1666.33 \mathrm{~b}$ & $28.61 \mathrm{~b}$ & $341.46 \mathrm{c}$ & $166.70 \mathrm{c}$ \\
\hline $\mathrm{NAFT}^{\circledR}$ & $328.65 \mathrm{~b}$ & $1648.66 \mathrm{~b}$ & $26.67 \mathrm{~b}$ & $311.11 \mathrm{~d}$ & $163.88 \mathrm{c}$ \\
\hline Orobor $^{\circledR}$ & $430.22 \mathrm{a}$ & $2289.33 \mathrm{a}$ & $28.62 \mathrm{~b}$ & $278.23 \mathrm{e}$ & $151.69 \mathrm{~d}$ \\
\hline TA35 ${ }^{\circledR}$ & $423.40 \mathrm{a}$ & $2161.33 \mathrm{a}$ & $27.84 \mathrm{~b}$ & $275.69 \mathrm{e}$ & $151.24 \mathrm{~d}$ \\
\hline Extremo $^{\circledR}$ & $452.09 \mathrm{a}$ & $2390.33 \mathrm{a}$ & $27.85 \mathrm{~b}$ & $265.58 \mathrm{e}$ & $145.42 \mathrm{~d}$ \\
\hline Veget’Oil $^{\circledR}$ & $152.72 \mathrm{c}$ & $813.33 \mathrm{c}$ & $20.51 \mathrm{c}$ & $419.87 b$ & $193.51 \mathrm{~b}$ \\
\hline Silwet $^{\circledR}$ L-77 & $352.54 \mathrm{~b}$ & $1809.33 \mathrm{~b}$ & $25.95 \mathrm{~b}$ & $298.46 \mathrm{e}$ & $156.33 \mathrm{c}$ \\
\hline CV (\%) & 19.97 & 20.08 & 11.31 & 7.23 & 11.31 \\
\hline
\end{tabular}

${ }^{1}$ Values followed by the same lower-case letter within columns are not statistically different according to Scott-Knott's test $(\alpha=0.05)$.

Efficacy of 2,4-D/dicamba-adjuvants associations for Ipomoea spp. Control

Analysis of variance indicated a significant AxB interaction for Ipomoea spp. control levels at 7 , 14, and 21 DAT (Table 4), as well as dry aboveground biomass (Table 5). At 28 DAT, only the untreated control treatment had significantly lower Ipomoea spp. control levels (data not shown). Treatments containing 2,4-D were found to display greater percent control levels relative to those containing dicamba at 7 and 14 DAT (Table 4), indicating faster herbicidal action; however, albeit still significant, such differences decreased at 21 and 28 DAT.

Both control and dry aboveground biomass data (Tables 4 and 5, respectively) indicate that the use of adjuvants did not increase 2,4-D phytotoxicity in Ipomoea spp. plants. Most Ipomoea spp. control values were similar to the adjuvant-free treatment, as was the case for all dry aboveground biomass results following 2,4-D spraying, regardless of the addition of adjuvants to the solution mix. Therefore, differences in the spray solution and droplet properties caused by adjuvants did not seem to have impacted 2,4-D performance at the present study. 
Table 4. Ipomoea spp. control levels at 7, 14, and 21 after treatment (DAT) for multiple 2,4-D and dicamba combinations with adjuvants.

\begin{tabular}{|c|c|c|c|c|c|c|c|c|c|c|c|c|}
\hline \multirow{4}{*}{$\begin{array}{r}\text { Adjuvants } \\
\text { No adjuvant }\end{array}$} & \multicolumn{4}{|c|}{$7 \mathrm{DAT}$} & \multicolumn{4}{|c|}{$14 \mathrm{DAT}$} & \multicolumn{4}{|c|}{$21 \mathrm{DAT}$} \\
\hline & \multicolumn{12}{|c|}{ Herbicides } \\
\hline & \multicolumn{2}{|c|}{$2,4-\mathrm{D}^{1}$} & \multicolumn{2}{|c|}{ Dicamba } & \multicolumn{2}{|c|}{$2,4-\mathrm{D}$} & \multicolumn{2}{|c|}{ Dicamba } & \multicolumn{2}{|c|}{$2,4-\mathrm{D}$} & \multicolumn{2}{|c|}{ Dicamba } \\
\hline & 63 & $\mathrm{Aa}$ & 43 & $\mathrm{Ba}$ & 98 & $\mathrm{Aa}$ & 67 & $\mathrm{Bb}$ & 99 & $\mathrm{Aa}$ & 88 & $\mathrm{Ba}$ \\
\hline $\mathrm{DASH}^{\circledR} \mathrm{HC}$ & 69 & Aa & 37 & $\mathrm{Ba}$ & 99 & $\mathrm{Aa}$ & 68 & $\mathrm{Bb}$ & 99 & $\mathrm{Aa}$ & 82 & $\mathrm{Bb}$ \\
\hline $\operatorname{Li} 700^{\circledR}$ & 62 & Aa & 30 & $\mathrm{Bb}$ & 98 & $\mathrm{Aa}$ & 70 & $\mathrm{Bb}$ & 98 & Aa & 88 & $\mathrm{Ba}$ \\
\hline $\mathrm{NAFT}^{\circledR}$ & 62 & $\mathrm{Aa}$ & 38 & $\mathrm{Ba}$ & 99 & $\mathrm{Aa}$ & 76 & $\mathrm{Ba}$ & 99 & $\mathrm{Aa}$ & 87 & $\mathrm{Ba}$ \\
\hline Orobor $^{\circledR}$ & 57 & $\mathrm{Ab}$ & 33 & $\mathrm{Bb}$ & 99 & $\mathrm{Aa}$ & 75 & $\mathrm{Ba}$ & 99 & $\mathrm{Aa}$ & 83 & $\mathrm{Bb}$ \\
\hline TA35 ${ }^{\circledR}$ & 61 & $\mathrm{Aa}$ & 38 & $\mathrm{Ba}$ & 99 & $\mathrm{Aa}$ & 72 & $\mathrm{Ba}$ & 99 & $\mathrm{Aa}$ & 92 & $\mathrm{Ba}$ \\
\hline Extremo $^{\circledR}$ & 53 & $\mathrm{Ab}$ & 25 & $\mathrm{Bb}$ & 98 & $\mathrm{Aa}$ & 65 & $\mathrm{Bb}$ & 99 & $\mathrm{Aa}$ & 87 & $\mathrm{Ba}$ \\
\hline Veget’Oil $^{\circledR}$ & 53 & $\mathrm{Aa}$ & 25 & $\mathrm{Ba}$ & 98 & $\mathrm{Aa}$ & 65 & $\mathrm{Bb}$ & 99 & $\mathrm{Aa}$ & 83 & $\mathrm{Bb}$ \\
\hline Silwet ${ }^{\circledR}$ L-77 & 59 & $\mathrm{Ab}$ & 37 & $\mathrm{Ba}$ & 96 & $\mathrm{Aa}$ & 69 & $\mathrm{Bb}$ & 99 & $\mathrm{Aa}$ & 88 & $\mathrm{Ba}$ \\
\hline Factorial $^{2}$ & \multicolumn{4}{|c|}{47.29} & \multicolumn{4}{|c|}{84.19} & \multicolumn{4}{|c|}{92.91} \\
\hline Untreated control & \multicolumn{4}{|c|}{0} & \multicolumn{4}{|c|}{0} & \multicolumn{4}{|c|}{0} \\
\hline CV (\%) & \multicolumn{4}{|c|}{11.6} & \multicolumn{4}{|c|}{6.94} & \multicolumn{4}{|c|}{4.28} \\
\hline
\end{tabular}

${ }^{1}$ Weed control values are percent control compared to untreated plants; values followed by the same lower-case letter within columns, and upper-case letter within lines are not statistically different according to Scott-Knott's test $(\alpha=0.05)$. Upper-case letters are comparisons across evaluation dates only; ${ }^{2}$ Difference between the grand experimental average and the additional untreated control treatment, according to Scott-Knott's test $(\alpha=0.05)$.

At 14 DAT, dicamba control of Ipomoea spp. plants was slightly better when $\mathrm{NAFT}^{\circledR}$, Orobor $^{\mathbb{B}}$, and TA35 were added to it. Lower percent control values at 21 DAT were noticed when DASH $^{\circledR} \mathrm{HC}$, Veget' Oil $^{\circledR}$, and Orobor ${ }^{\circledR}$ adjuvants were used; however, such differences disappeared at 28 DAT. Similarly, to 2,4-D, the use of adjuvants did not increase dicamba phytotoxicity onto Ipomoea spp. plants, in spite of any droplet size and surface tension alterations, mentioned previously. Due to its faster action, 2,4-D-containing treatments scored lower dry aboveground biomass values in comparison to treatments containing dicamba (Table 5). Among adjuvants, there were no observed differences when these were added to 2,4-D. However, adding Veget' Oil ${ }^{\circledR}, \mathrm{TA}^{\circledR} 5^{\circledR}$, and $\mathrm{Li} 700^{\circledR}$ to dicamba was found to allow greater dry biomass accumulation relative to all other treatments, including the adjuvant-free control. Despite these differences, Ipomoea spp. control at 28 DAT (last evaluation date) following dicamba applications was similar across treatments. The efficient use of auxin herbicides for Ipomoea spp. control is knowingly dependent on applications taking place at the recommended growth stage (OSIPE et al., 2017). 2,4-D spraying onto adult developed I. triloba plants have been shown to lead to poor control levels, whereas the use of adjuvants could help increase control efficacy in those situations (CAMPOS et al., 2009). The addition of non-ionic surfactants and paraffin oil-based adjuvants to fomesafen and bentazon-containing tank-mixes, respectively, was found to improve broadleaf weed control when plants were sprayed at more advanced growth stages (BELLINDER et al., 2003). These results exacerbate the importance of choosing which adjuvant to add to herbicide tank-mixes, as some might present an alternative to modify spray solution and drop properties without causing loss of herbicidal efficacy, as shown at the present work. 
Table 5. Dry aboveground biomass (DAB) of Ipomoea spp. plants collected at 28 days after treatment (DAT) with multiple 2,4-D or dicamba combinations with adjuvants.

\begin{tabular}{|c|c|c|}
\hline \multirow{3}{*}{ Adjuvants } & \multicolumn{2}{|c|}{ DAB 28 DAT $\left(\mathrm{g} \mathrm{m}^{-2}\right)$} \\
\hline & \multicolumn{2}{|c|}{ Herbicides } \\
\hline & $2,4-\mathrm{D}^{1}$ & Dicamba \\
\hline No adjuvant & $28 \mathrm{Ba}$ & $63 \mathrm{Ab}$ \\
\hline $\mathrm{DASH}^{\circledR} \mathrm{HC}$ & $27 \mathrm{Ba}$ & $60 \mathrm{Ab}$ \\
\hline $\operatorname{Li700}^{\circledR}$ & $34 \mathrm{Ba}$ & $94 \mathrm{Aa}$ \\
\hline $\mathrm{NAFT}^{\circledR}$ & $45 \mathrm{Aa}$ & $47 \mathrm{Ab}$ \\
\hline Orobor $^{\mathbb{R}}$ & $34 \mathrm{Ba}$ & $67 \mathrm{Ab}$ \\
\hline TA35 ${ }^{\circledR}$ & $37 \mathrm{Ba}$ & $97 \mathrm{Aa}$ \\
\hline Extremo $^{\circledR}$ & $32 \mathrm{Ba}$ & $68 \mathrm{Ab}$ \\
\hline Veget'Oil $^{\circledR}$ & $52 \mathrm{Ba}$ & $88 \mathrm{Aa}$ \\
\hline Silwet $^{\circledR}$ L-77 & $59 \mathrm{Aa}$ & $35 \mathrm{Ab}$ \\
\hline Factorial $^{2}$ & \multicolumn{2}{|c|}{54} \\
\hline Untreated control & \multicolumn{2}{|c|}{132} \\
\hline CV (\%) & \multicolumn{2}{|c|}{27.99} \\
\hline
\end{tabular}

\section{CONCLUSIONS}

All adjuvants employed at the present work caused a variety of modifications on spray solution properties such as its $\mathrm{pH}$, also leading to lower surface tension values. Most adjuvants caused an overall decrease in number and density of droplets due to an increase in droplet diameter and volumetric mean diameter. The addition of adjuvants to 2,4-D or dicamba applications interfered with their herbicidal efficacy for Ipomoea spp. control. 2,4-D had a quicker effect on Ipomoea spp. control relative to dicamba, regardless of adjuvant usage, resulting in lower dry aboveground biomass accumulation when treatments contained 2,4-D rather than dicamba. However, dicambacontaining treatments displayed slightly lower Ipomoea spp. control levels at the end of the evaluation period following herbicide usage. Lastly, the efficacy of neither 2,4-D nor dicamba was improved when adjuvants were added to the spraying solution. Their use, however, should still be considered given the alterations that took place in the spraying solution, especially with a relation with the possible spray drift losses with this nozzle and adjuvants.

\section{ACKNOWLEDGEMENTS}

The authors would like to recognize and thank the Coordination for the Improvement of Higher Education Personnel (CAPES/Brazil) for providing financial aid and scholarships, and staff at the Department of Crop Protection (UFSM/RS, Brazil) for their help during field and lab work related to this project.

RESUMO: Os herbicidas mimetizadores da auxina constituem alternativas importantes para o manejo de plantas daninhas de difícil controle, como Ipomoea spp. Sabe-se que o uso de adjuvante afeta positivamente a eficácia biológica dos pesticidas, modificando as principais propriedades da solução e do espectro de gotas da pulverização. Os objetivos desse trabalho foram determinar em que medida o uso de adjuvantes pode alterar os parâmetros da solução de pulverização e afetar a eficiência dos herbicidas mimetizadores da auxina para Ipomoea spp. Os estudos foram conduzidos em duas fases: em laboratório e em campo. Em laboratório foi avaliado o pH, tensão superficial e características das gotas dos herbicidas. Em campo foi avaliado o controle 
da planta daninha. Todos os adjuvantes modificaram as propriedades da solução de pulverização, diminuindo os valores de tensão superficial. A maioria dos adjuvantes diminuiu os valores de $\mathrm{pH}$, bem como o número e a densidade de gotas. Independentemente do uso de adjuvante, os níveis de controle de Ipomoea spp. aumentaram mais rapidamente após a pulverização com 2,4-D do que com o dicamba, resultando em menor acúmulo de biomassa quando o primeiro foi usado. Os tratamentos contendo dicamba apresentaram ligeiramente menor controle de Ipomoea spp. A aplicação de 2,4-D promoveu menor biomassa e maiores níveis de controle em relação ao dicamba de Ipomoea spp., sugerindo que possa constituir uma opção melhor de controle. Embora a eficácia do herbicida não tenha sido melhorada com adjuvantes, seu uso ainda deve ser considerado com alterações favoráveis da solução de pulverização, principalmente tamanhos de gotas em qualquer uso de pontas de pulverização - mantendo a eficácia do controle de plantas daninhas.

PALAVRAS-CHAVE: Auxinas. Corriola. pH. Tensão superficial.

\section{REFERENCES}

AGROFIT. Sistema de Agrotóxicos Fitossanitários. Ministério da Agricultura, Pecuária e Abastecimento. Available from: $<$ http://agrofit.agricultura.gov.br/agrofit_cons/principal_agrofit_cons $>$ Accessed in October 25 2019.

BELLINDER, R. R.; ARSENOVIC, M.; SHAH, D. A.; RAUCH, B. J. Effect of weed growth stage and adjuvant on the efficacy of fomesafen and bentazon. Weed Science, Westminster, v. 51, n. 6, p. 1016-1021, 2003. https://doi.org/10.1614/P2002-047

BUTTS, T. R.; SAMPLES, C. A.; FRANCA L. X.; DODDS D. M.; REYNOLDS D. B.; ADAMS J. W.; KRUGER G. R. Spray droplet size and carrier volume effect on dicamba and glufosinate efficacy. Pest Management Science, London, v. 74, n. 9, p. 2020-2029, 2018. https://doi.org/10.1002/ps.4913.

CAMPOS, L. H. F.; FRANCISCO, M. O.; CARVALHO, S. J. P.; NICOLAI, M.; CHRISTOFFOLETI, P. J. Susceptibility of Ipomoea quamoclit, I. triloba and Merremia cissoides to the Herbicides Sulfentrazone and Amicarbazone. Planta Daninha, Viçosa, v. 27, n. 4, p. 831-840, 2009. http://dx.doi.org/10.1590/S0100$\underline{83582009000400022}$

CASTRO, E. B.; CARBONARI, C. A.; VELINI, E. D.; GOMES, G. L. G. C.; BELAPART, D. Influence of adjuvants on the surface tension, deposition, and effectiveness of herbicides on fleabane plants. Planta daninha, Viçosa, v. 36, 2018. http://dx.doi.org/10.1590/s0100-83582018360100067

CHAUHAN, B. S.; ABUGHO, S. B. Threelobe Morningglory (Ipomoea triloba) Germination and Response to Herbicides. Weed Science, Westminster, v. 60, n. 2, p. 199-204, 2012. https://doi.org/10.1614/WS-D-11$\underline{00137.1}$

CHELME-AYALA, P.; EL-DIN, M. G. S; MITH, D. W. Degradation of bromoxynil and trifluralin in natural water by direct photolysis and UV plus $\mathrm{H}_{2} \mathrm{O}_{2}$ advanced oxidation process. Water Research, London, v. 44, $\mathrm{n}$. 7, p. 2221-2228, 2010. https://doi.org/10.1016/j.watres.2009.12.045

COSTA, L. L.; SILVA, H. J.; ALMEIDA, D. P.; FERREIRA, M. D. C.; PONTES, N. D. C. Droplet spectra and surface tension of spray solutions by biological insecticide and adjuvants. Engenharia Agricola, Jaboticabal, v. 37, n. 2, p. 292-301, 2017. http://dx.doi.org/10.1590/1809-4430-eng.agric.v37n2p292-301/2017

CREECH, C. F.; MORAES, J. G.; HENRY, R. S.; LUCK, J. D.; KRUGER, G. R. The Impact of Spray Droplet Size on the Efficacy of 2,4-D, Atrazine, Chlorimuron-Methyl, Dicamba, Glufosinate, and Saflufenacil. Weed Technology, Westmisnter, v. 30, n. 2, p. 573-586, 2016. https://doi.org/10.1614/WT-D-15-00034.1 
DE SCHAMPHELEIRE, M.; NUYTTENS, D.; BAETENS, K.; CORNELIS, W.; GABRIELS, D.; SPANOGHE, P. Effects on pesticide spray drift of the physicochemical properties of the spray liquid. Precision Agriculture, Dordrecht, v. 10, n. 5, p. 409-420, 2009. https://doi.org/10.1007/s11119-008-9089-6

DEVKOTA, P.; JOHNSON, W. G. Glufosinate Efficacy as Influenced by Carrier Water pH, Hardness, Foliar Fertilizer, and Ammonium Sulfate. Weed Technology, Westminster, v. 30, n. 4, p. 848-859, 2016. https://doi.org/10.1614/WT-D-16-00053.1

DEVKOTA, P.; JOHNSON, W. G. Influence of carrier water $\mathrm{pH}$, foliar fertilizer, and ammonium sulfate on 2,4-D and 2,4-D plus glyphosate efficacy. Weed Technology, Westminster, v. 33, n. 4, p. 562-568, 2019. https://doi.org/10.1017/wet.2019.31

FERREIRA, E. B.; CAVALCANTI, P. P.; NOGUEIRA, D. A. ExpDes: An R Package for ANOVA and Experimental Designs. Applied Mathematics, Wuhan, v. 5, n. 19, p. 2952-2958, 2014. https://doi.org/10.4236/am.2014.519280

FRANS, R. Experimental design and techniques for measuring and analyzing plant responses to weed control practices. In: CAMPER, N.D. (Ed.) Research methods in weed science. 3 ed. Champaign: Southern Weed Science Society, 1986.

GIMENES, M. J.; ZHU, H.; RAETANO, C. G.; OLIVEIRA, R. B. Dispersion and evaporation of droplets amended with adjuvants on soybeans. Crop Protection, Guildford, v. 44, p. 84-90, 2013. https://doi.org/10.1016/j.cropro.2012.10.022

GREEN, J. M. Current state of herbicides in herbicide-resistant crops. Pest Management Science, London, v. 70, n. 9, p. 1351-1357, 2014. https://doi.org/10.1002/ps.3727

GROSSMANN, K. Auxin herbicides: Status of mechanism and mode of action. Pest Management Science, Londom, v. 66, n. 2, p. 113-120, 2009. https://doi.org/10.1002/ps.1860

HEWITT, A. J. Droplet size spectra classification categories in aerial application scenarios. Crop Protection, Guildford, v. 27, n. 9, p. 1284-1288, 2008. https://doi.org/10.1016/j.cropro.2008.03.010

KOEPKE-HILL, R. M.; ARMEL, G. R.; BROSNAN, J. T.; BREEDEN, G. K.; VARGAS, J. J.; MUELLER, T. C. Control of Silk Tree (Albizia julibrissin) with aminocyclopyrachlor and other herbicides. Weed Science, Westminster, v. 60, n. 3, p. 345-349, 2012. https://doi.org/10.1614/WS-D-11-00161.1

LEON, R. G.; FERRELL, J. A.; SELLERS, B. A. Seed Production and Control of Sicklepod (Senna obtusifolia) and Pitted Morningglory (Ipomoea lacunosa) with 2,4-D, Dicamba, and Glyphosate Combinations. Weed Technology, Westminster, v. 30, n. 1, p. 76-84, 2016. https://doi.org/10.1614/WT-D-15-00108

MELO, A. A.; HUNSCHE, M.; GUEDES, J. V.; HAHN, L.; FELTRIN, N. M. Study of the effects of adjuvants associated with insecticides on the physicochemical properties of the spray solution and characterization of deposits on wheat and maize leaves under simulated rain. Engenharia Agrícola, Jaboticabal, v. 39, n. 3, p. 315-322, 2019. http://dx.doi.org/10.1590/1809-4430-eng.agric.v39n3p315-322/2019

MOTA, A. A. B.; ANTUNIASSI, U. Influência de adjuvantes no espectro de gotas de ponta com indução de ar. Energia na Agricultura, Botucatu, v. 28, n. 1, p. 01-05, 2013.

https://doi.org/10.17224/EnergAgric.2013v28n1p01-05

MUELLER, T. C.; STECKEL, L. E. Spray mixture $\mathrm{pH}$ as affected by dicamba, glyphosate, and spray additives. Weed Technology, Westminster, v. 33, n. 4, p. 547, 554, 2019. https://doi.org/10.1017/wet.2019.40 
OSIPE, J. B.; OLIVEIRA JR, R. S.; CONSTANTIN, J.; TAKANO, H. K.; BIFFE, D. F. Espectro de controle de plantas daninhas com os herbicidas 2,4-D e dicamba associados ou não ao glyphosate. Planta Daninha, Viçosa, v. 35, 2017. http://dx.doi.org/10.1590/s0100-83582017350100053

ROSKAMP, J. M.; JOHNSON, W. G. The Influence of Adjusting Spray Solution pH on the Efficacy of Saflufenacil. Weed Technology, Westminster, v. 27, n. 3, p. 445-447, 2013. https://doi.org/10.1614/WT-D-12$\underline{00129.1}$

STAUFFER, C. E. The measurement of surface tension by the pendant drop technique. The Journal of Physical Chemistry, Washington, v. 69, n. 6, p. 1933-1938, 1965. https://doi.org/10.1021/j100890a024

TAKANO, H. K.; OLIVEIRA JUNIOR, R. S. O.; CONSTANTIN, J.; BIFFE, D. F.; FRANCHINI, L. H. M.; BRAZ, G. B. P.; RIOS, F. A.; GHENO, E. A.; GEMELLI, A. Effect of 2.4-D addition to glyphosate for difficult control weeds species. Revista Brasileira de Herbicidas, Londrina, v. 12, n. 1, p. 1-13, 2013. https://doi.org/10.7824/rbh.v12i1.207 